\title{
RECOVERY OF SALEABLE SALTS FROM OCCURRING NATURAL BRINES REPRESENTING THE QUINARY AQUEOUS SYSTEM Na-K-Mg-Ca-Cl
}

\author{
Ruberlan Gomes da Silva ${ }^{1,2}$ \\ Marcelo Seckler ${ }^{3}$ \\ Sonia Denise Ferreira Rocha ${ }^{4}$ \\ Daniel Saturnino ${ }^{2}$ \\ Éder Domingos de Oliveira ${ }^{2}$
}

\begin{abstract}
Potassium chloride $(\mathrm{KCl})$ accounts for most of the potassium $(\mathrm{K})$ used in world agriculture and represents $96 \%$ of the world potash capacity. The other $4 \%$ includes potassium sulfate $\left(\mathrm{K}_{2} \mathrm{SO}_{4}\right)$, potassium nitrate $\left(\mathrm{KNO}_{3}\right)$ and potassium-magnesium based salts. In this sense, the prediction of the solubility of electrolytes in aqueous solutions is important to provide data for processes that extract potassium salts from multicomponent brines. In this work, Pitzer's and Harvie's models were used to calculate the amount and composition of crystallized salts after water evaporation. The process involved four crystallization steps starting from multicomponent brines represented by the quinary $\mathrm{Na}-\mathrm{K}-\mathrm{Ca}-\mathrm{Mg}-\mathrm{Cl}$ aqueous system at $20^{\circ} \mathrm{C}$. The temperature of $20^{\circ} \mathrm{C}$ was chosen because it is the average process brine temperature in many dry salt lakes. The Pitzer's and Harvie's models allowed performing a material balance in solar ponds producing saleable salts like sodium, potassium, magnesium and calcium chlorides.
\end{abstract}

Keywords: Crystallization; Potassium; Quinary Na-K-Ca-Mg-Cl Aqueous System.

\section{RECUPERAÇÃO DE SAIS COMERCIAIS A PARTIR DE UMA SALMOURA NATURAL REPRESENTATIVA DO SISTEMA QUINÁRIO Na-K-Mg-Ca-Cl}

\section{Resumo}

O cloreto de potássio $(\mathrm{KCl})$ é uma das principais fontes de potássio $(\mathrm{K})$ usada na agricultura e corresponde a $96 \%$ do consumo mundial desse nutriente. Os outros $4 \%$ incluem o sulfato de potássio $\left(\mathrm{K}_{2} \mathrm{SO}_{4}\right)$, nitrato de potássio $\left(\mathrm{KNO}_{3}\right)$ e os sais duplos de potássio e magnésio. A previsão da solubilidade dos eletrólitos em soluções aquosas é importante na estimativa dos parâmetros de processos da rota de processo a ser usada na extração seletiva dos sais de potássio presentes em salmouras multicomponente. Nesse sentido, os modelos de Pitzer e Harvie foram usados nas estimativas das quantidades e das composições dos sais cristalizados após evaporação da água. A rota de processo envolve quatro etapas de cristalização de uma salmoura representativa do sistema aquoso quinário $\mathrm{Na}-\mathrm{K}-\mathrm{Mg}-\mathrm{Ca}-\mathrm{Cl}$ na temperatura de $20^{\circ} \mathrm{C}$. A temperatura de $20^{\circ} \mathrm{C}$ foi escolhida por ser a temperatura média das salmouras verificadas nos salares Andinos. Os resultados obtidos com os modelos de Pitzer e Harvie permitiram a elaboração do balanço de massa e energia das piscinas de evaporação e obtenção dos sais comerciais: cloretos de sódio, potássio, magnésio e cálcio.

Palavras-chave: Cristalização; Potássio; Sistema Aquoso Quinário Na-K-Ca-Mg-Cl.

\section{INTRODUCTION}

The knowledge of solubility of electrolytes in aqueous solutions is essential for the development of many processes such as brines and seawater desalination, salting-out crystallization and liquid-liquid extraction in chemical, mineral and hydrometallurgical industries [I]. For example, high evaporation rates and minimal rainfall in northern regions

'Centro de Desenvolvimento Mineral da Vale-CDM, Santa Luzia, MG, Brasil.E-mail: ruberlan.silva@hotmail.com; ruberlan.silva@vale.com 2Departamento de Engenharia Química, Universidade Federal de Minas Gerais - UFMG, Belo Horizonte, MG, Brasil.

${ }^{3}$ Departamento de Engenharia Química, Universidade de São Paulo - USP, São Paulo, SP, Brasil.

${ }^{4}$ Departamento de Engenharia de Minas, Universidade Federal de Minas Gerais - UFMG, Belo Horizonte, MG, Brasil. 
of Argentina and Chile allow solar evaporation ponds to produce commercial salts from natural brines, like potassium chloride, potassium sulfate and lithium salts [2].

The processing of brines from Qarhan Salt Lake (China) containing $\mathrm{K}^{+}, \mathrm{Na}^{+}, \mathrm{Mg}^{+2}$ and $\mathrm{Cl}^{-}$follows the crystallization sequence: $\mathrm{NaCl} \rightarrow \mathrm{NaCl}+\mathrm{KCl} \rightarrow \mathrm{NaCl}+\mathrm{KCl} \cdot \mathrm{MgCl} 2 \cdot 6 \mathrm{H}_{2} \mathrm{O}$ $\rightarrow \mathrm{NaCl}+\mathrm{KCl} \cdot \mathrm{MgCl}_{2}+\mathrm{MgCl}_{2} \cdot 6 \mathrm{H}_{2} \mathrm{O}$. In this process, during carnallite $\left(\mathrm{KCl} \cdot \mathrm{MgCl}_{2} \cdot 6 \mathrm{H}_{2} \mathrm{O}\right)$ formation step, $\mathrm{NaCl}$ is always associated with carnallite as mixed crystals. . Therefore $12-25 \% \mathrm{w} / \mathrm{w} \mathrm{NaCl}$ has to be separated first in order to produce pure $\mathrm{KCl}$ by carnallite decomposition [3]. Similarly, all resulting multicomponent brines have to be processed to deliver the individual salts with purities compatible with market-grade products.

Thermodynamic models are a usual tool to design and evaluate the facilities that produce salts with market-grade purities. For example, the Pitzer and Harvie's model agrees well with literature data on both: the binary systems $\left(\mathrm{NaCl}-\mathrm{H}_{2} \mathrm{O}, \mathrm{KCl}-\mathrm{H}_{2} \mathrm{O}\right.$ and $\left.\mathrm{MgCl}_{2}-\mathrm{H}_{2} \mathrm{O}\right)$ and on the ternary systems $\left(\mathrm{NaCl}-\mathrm{KCl}-\mathrm{H}_{2} \mathrm{O}\right)$ at $20^{\circ} \mathrm{C}$ as already published [4]. The process is based on the separation of inorganic salts from a multicomponent system using fractional crystallization [5]. To this end, Pitzer's ion-interaction model [6] and its extended Harvie and Weare's model $[7,8]$ are suitable tools, because they are reliable in predicting the mineral solubility of multicomponent salt systems in natural waters with high ionic strength ( 0 to 6 molal), over a wide range of temperatures $\left(0\right.$ to $\left.300^{\circ} \mathrm{C}\right)$ [8-10].

A complete study for the system $\mathrm{Na}-\mathrm{K}-\mathrm{Mg}-\mathrm{Ca}-\mathrm{H}-$ $\mathrm{Cl}-\mathrm{SO}_{4}-\mathrm{OH}-\mathrm{HCO}_{3}-\mathrm{CO}_{3}-\mathrm{CO}_{2}-\mathrm{H}_{2} \mathrm{O}$ was carried out at $25^{\circ} \mathrm{C}$ by Harvie et al. [7]. The authors used the salts solubilities in the ternary ion system to obtain the mixture parameters and also to determine the chemical potentials of some of the solid phases. A similar procedure was used to predict the solubilities of the $\mathrm{Na}-\mathrm{K}-\mathrm{Mg}-\mathrm{Cl}-\mathrm{SO}_{4}-\mathrm{OH}-\mathrm{H}_{2} \mathrm{O}$ system at several temperatures [9]. The equations for the calculation of the solubilities of halite, sylvite and carnallite, individually or combined, have been set up by Marcus and Soffer [II] for the quinary system $\mathrm{NaCl}-\mathrm{KCl}-\mathrm{MgCl}-\mathrm{CaCl}_{2}-\mathrm{H}_{2} \mathrm{O}$ at $25^{\circ} \mathrm{C}$.

Thus, the objective of this study is to understand the equilibrium of the quinary aqueous system $\mathrm{Na}-\mathrm{K}-\mathrm{Mg}-\mathrm{Ca}-\mathrm{Cl}$, using synthetic pulps with different amounts of $\mathrm{NaCl}, \mathrm{KCl}$, $\mathrm{MgCl}_{2} \cdot 6 \mathrm{H}_{2} \mathrm{O}$ and $\mathrm{CaCl}_{2} \cdot 2 \mathrm{H}_{2} \mathrm{O}$ analytical grade salts. To this end, solubility data measured at $20^{\circ} \mathrm{C}$ for liquors and solids in equilibrium, representing the aqueous $\mathrm{Na}-\mathrm{K}-\mathrm{Mg}-\mathrm{Ca}-\mathrm{Cl}$ system, were compared with the solubilities calculated based on Pitzer's and Harvie's ion-interaction models. The idea was to verify the capability to predict the behavior of the system after the removal of different amounts of water by evaporation. The motivation behind this study is to obtain data to help in evaluating the technical and economic feasibility of operations in natural occurring brines, representing the aqueous $\mathrm{Na}-\mathrm{K}-\mathrm{Mg}-\mathrm{Ca}-\mathrm{Cl}$ system. The purpose would be to obtain saleable salts, like magnesium and calcium chlorides, as well as sodium and potassium chlorides, at grades matching market specifications.

\section{METHODOLOGY}

Phase equilibrium at $20^{\circ} \mathrm{C}$ in the quinary system was studied using the isothermal dissolution method [12]. Batch crystallization experiments with synthetic pulps were conducted using a thermostatic shaker from Innova 44 model New Brunswick, with temperature controlled to $0.02 \mathrm{~K}$. Analytical grade salts from Merck: sodium chloride $(\mathrm{NaCl}, 99.5 \mathrm{wt} \%)$, potassium chloride $(\mathrm{KCl}, 99.5 \mathrm{wt} \%)$, magnesium chloride $\left(\mathrm{MgCl}_{2} .6 \mathrm{H}_{2} \mathrm{O}, 99.5 \% \mathrm{wt} \%\right)$ and calcium chloride $\left(\mathrm{CaCl}_{2} \cdot 2 \mathrm{H}_{2} \mathrm{O}, 99.5\right.$ wt\%) and double- deionized water were used to prepare the various slurries. Stirring was provided by a mechanical stirrer at 200 RPM, using a $45^{\circ}$ pitched blade impeller. Table I shows the amount of salts used to prepare the exploratory five synthetic pulps. All pulps were saturated with $\mathrm{NaCl}$. The difference of the three first pulps was the amount of water to evaluate the effect of water in the crystallization by evaporation. The fourth pulp had a reduced amount of $\mathrm{NaCl}$ in order to evaluate the behaviour of $\mathrm{KCl}, \mathrm{MgCl}_{2}$ and $\mathrm{CaCl}_{2}$ and, in the fifth, the amounts of $\mathrm{NaCl}$ and $\mathrm{KCl}$ were reduced to analyse the behaviour of $\mathrm{MgCl}_{2}$ and $\mathrm{CaCl}_{2}$.

The pulps were distributed in five recipients and stirred for 48 hours at 200 RPM in order to achieve equilibrium. The pulps in equilibrium at $20^{\circ} \mathrm{C}$ were vacuum filtered using $0.22 \mu \mathrm{m}$ membranes. The temperature of $20^{\circ} \mathrm{C}$ was chosen because it is the average process brine temperature in most salt lake operations [2].

The liquid phases were diluted with double-deionized water to determine the sodium, potassium, magnesium and calcium contents with a GBCPlus Atomic Absorption Spectrometer. The chloride concentrations in the liquid phases were determined by titration with a standard solution of $\mathrm{AgNO}_{3}$ in the presence of drops of $0.1 \%(\mathrm{w} / \mathrm{v}) \mathrm{K}_{2} \mathrm{CrO}_{4}$ as an indicator.

Solids samples for X-ray diffraction were ground below 200 \# TYLER MESH and analyzed on a PANalytical Model X'PERT PRO MPD (PW 34I9) with a PW3050/60 $(\theta / \theta)$ goniometer, $\mathrm{X}$-ray ceramics tubes, anode of $\mathrm{Cu}$ $(\mathrm{K} \alpha \mathrm{I}=\mathrm{I}, 540598 \AA)$ and PW3373/00 model (2000 W-60kV). Diffraction patterns were acquired from $5^{\circ}$ to $75^{\circ}, 2 \theta$ at 0.02 steps. The identification of all minerals was done with $X$ ' Pert High Score version 2. I b software from PANalytical.

Table I. Amounts of salts and water used to prepare the five synthetic pulps

\begin{tabular}{cccccc}
\hline $\begin{array}{c}\text { Test } \\
\text { Number }\end{array}$ & $\begin{array}{c}\mathbf{N a C l} \\
(\mathbf{g})\end{array}$ & $\begin{array}{c}\mathbf{K C l} \\
(\mathbf{g})\end{array}$ & $\begin{array}{c}\mathbf{M g C l}_{2} \cdot \mathbf{6} \mathbf{H}_{\mathbf{2}} \mathbf{O} \\
(\mathbf{g})\end{array}$ & $\begin{array}{c}\mathbf{C a C l}_{2} . \mathbf{2} \mathbf{H}_{2} \mathbf{O} \\
(\mathbf{g})\end{array}$ & $\begin{array}{c}\mathbf{H}_{2} \mathbf{O} \\
(\mathbf{g})\end{array}$ \\
\hline $\mathrm{I}$ & 57.47 & 4.05 & 14.16 & 18.23 & 188.02 \\
2 & 57.47 & 4.05 & 14.16 & 18.23 & 88.02 \\
3 & 57.47 & 4.05 & 14.16 & 18.23 & 68.02 \\
4 & 0.70 & 4.05 & 14.16 & 18.23 & 28.02 \\
5 & 0.70 & 0.05 & 14.16 & 18.23 & 8.01 \\
\hline
\end{tabular}




\section{RESULTS AND DISCUSSION}

The results are shown in two separate sections. In the first, the solubilities of interest are calculated using the thermodynamic models and the experimental data are compared to the solubilities calculated by the models. In the second section, a material balance for a solar evaporation pond is developed to estimate the production of market-grade salts.

\section{I Solubility Predicted by Pitzer's and Harvie's Models}

The theory used to calculate the salts solubilities was described by Silva et al. (2016) according to reference [4]. Experimentally determined equilibrium compositions of liquid and solids phases from five synthetic pulps are shown in Table 2 and Table 3. The Pitzer's and Harvie's models results are presented in Table 4.

From Table 2 and Table 4, it is seen that the liquid phases obtained from tests I, 2 and 3 are all saturated with $\mathrm{NaCl}$, while the low $\mathrm{NaCl}$ contents, in the solid salts from tests 4 and 5 , could be due to their respective impregnated liquid phases. The high amount of solids in equilibrium with the respective brine was founded in test $4,11 \% \mathrm{w} / \mathrm{w}$ of brine and $89 \% \mathrm{w} / \mathrm{w}$ of solids. The equilibrium liquid phase from test 5 is saturated with respect to several salts, as indicated in Table 3 and Table 4. It is noticed the presence of the most soluble salts, carnallite and calcium chloride included, in the solid phases of test 4 and test 5 , respectively. Table 4 presents the values of activities of water (aw), calculated by equation 6 from reference [I I], for the five liquid phases in equilibrium with the solids in each test. It is possible to check a reduction of water activity with the increase of total soluble solids.

Figure I shows a comparison between the compositions of equilibrium brines at $20^{\circ} \mathrm{C}$ calculated by Pitzer's and Harvie's models and obtained by the tests with synthetic pulps.

The simulated and experimental results of the synthetic pulps for the experimental concentrations of 2-2 electrolytes are shown in Figure Ia. Magnesium chloride $\left(\mathrm{MgCl}_{2}\right)$ and calcium chloride $\left(\mathrm{CaCl}_{2}\right)$ are in the equilibrium as well as

Table 2. Experimental liquid phase compositions from synthetic pulps

\begin{tabular}{|c|c|c|c|c|c|c|c|}
\hline \multirow{2}{*}{$\begin{array}{c}\text { Number } \\
\text { Test }\end{array}$} & \multirow{2}{*}{$\begin{array}{l}\% \text { mass fraction of equlibrium } \\
\text { liquid phases with the respective } \\
\text { solids }\end{array}$} & \multirow{2}{*}{$\begin{array}{c}\text { Density at } \\
20^{\circ} \mathrm{C}\left(\mathrm{g} \cdot \mathrm{cm}^{-3}\right)\end{array}$} & \multicolumn{5}{|c|}{$\begin{array}{l}\text { Liquid phase composition } \\
\qquad(\% w / w)\end{array}$} \\
\hline & & & $\mathrm{NaCl}$ & $\mathrm{KCl}$ & $\mathrm{MgCl}_{2}$ & $\mathrm{CaCl}_{2}$ & $\mathrm{H}_{2} \mathrm{O}$ \\
\hline Test I & 98 & 1.200 & 16.62 & 1.29 & 2.50 & 3.89 & 75.70 \\
\hline Test 2 & 77 & 1.215 & 14.50 & 2.60 & 4.19 & 12.46 & 66.26 \\
\hline Test 3 & 71 & 1.230 & 9.90 & 3.10 & 4.60 & 12.84 & 69.55 \\
\hline Test 4 & 11 & 1.300 & 1.48 & 2.00 & 4.88 & 14.03 & 77.61 \\
\hline Test 5 & 98 & I.370 & 0.32 & 0.02 & 5.55 & 28.19 & 65.92 \\
\hline
\end{tabular}

Table 3. Experimental solid phase compositions from synthetic pulps

\begin{tabular}{|c|c|c|c|c|c|c|}
\hline \multirow{2}{*}{$\begin{array}{l}\text { Number } \\
\text { Test }\end{array}$} & \multirow{2}{*}{$\begin{array}{c}\% \text { mass fraction of } \\
\text { equilibrium solid phase } \\
\text { with the respective } \\
\text { liquids }\end{array}$} & \multicolumn{4}{|c|}{$\begin{array}{c}\text { Solid phases compositions } \\
(\% \mathrm{w} / \mathrm{w})\end{array}$} & \multirow{2}{*}{ Solid phase identified by $x$-Ray diffraction } \\
\hline & & $\mathrm{NaCl}$ & $\mathrm{KCl}$ & $\mathrm{MgCl}_{2}$ & $\mathrm{CaCl}_{2}$ & \\
\hline Test I & 2 & 100 & 0 & 0 & 0 & $\mathrm{NaCl}$ \\
\hline Test 2 & 23 & 100 & 0 & 0 & 0 & $\mathrm{NaCl}$ \\
\hline Test 3 & 29 & 98 & 2 & 0 & 0 & $\mathrm{NaCl}, \mathrm{KCl}$ \\
\hline \multirow[t]{2}{*}{ Test 4} & 89 & I & 51 & 48 & 0 & $\mathrm{NaCl}, \mathrm{KCl}$, Carnallite \\
\hline & & & & & & $\left(\mathrm{KCl} . \mathrm{MgCl}_{2} \cdot 6 \mathrm{H}_{2} \mathrm{O}\right)$ and Bischofite $\left(\mathrm{MgCl}_{2} \cdot 6 \mathrm{H}_{2} \mathrm{O}\right)$ \\
\hline Test 5 & 2 & 1 & 6 & 9 & 84 & $\begin{array}{c}\mathrm{NaCl}, \mathrm{MgCl}_{2} \cdot 6 \mathrm{H}_{2} \mathrm{O}, \text { Tachyhydrite }\left(\mathrm{CaCl}_{2} \cdot \mathrm{MgCl}_{2} \cdot 12 \mathrm{H}_{2} \mathrm{O}\right) \text { and } \\
\text { Antractite } \mathrm{CaCl}_{2} \cdot 6 \mathrm{H}_{2} \mathrm{O}\end{array}$ \\
\hline
\end{tabular}

Table 4. Liquid phase compositions calculated by the Pitzer's and Harvie's models

\begin{tabular}{|c|c|c|c|c|c|c|c|}
\hline \multirow{3}{*}{ Number Test } & \multirow{3}{*}{$\begin{array}{c}\text { Density at } \\
20^{\circ} \mathrm{C}\left(\mathrm{g} \cdot \mathrm{cm}^{-3}\right)\end{array}$} & \multicolumn{5}{|c|}{ Liquid phase composition } & \multirow{3}{*}{$\begin{array}{l}\text { Activity of } \\
\text { water }\left(a_{w}\right)\end{array}$} \\
\hline & & \multicolumn{5}{|c|}{$(\% w / w)$} & \\
\hline & & $\mathrm{NaCl}$ & $\mathrm{KCl}$ & $\mathrm{MgCl}_{2}$ & $\mathrm{CaCl}_{2}$ & $\mathrm{H}_{2} \mathrm{O}$ & \\
\hline Test I & 1.200 & 15.25 & 1.53 & 2.50 & 5.20 & 75.52 & 0.729 \\
\hline Test 2 & 1.215 & 7.44 & 3.01 & 4.93 & 10.24 & 74.38 & 0.676 \\
\hline Test 3 & 1.230 & 5.01 & 2.59 & 6.10 & 12.67 & 73.62 & 0.642 \\
\hline Test 4 & 1.300 & 1.13 & 1.09 & 5.97 & 23.50 & 68.30 & 0.492 \\
\hline Test 5 & 1.370 & 0.15 & 0.26 & 18.68 & 15.40 & 65.52 & 0.298 \\
\hline
\end{tabular}



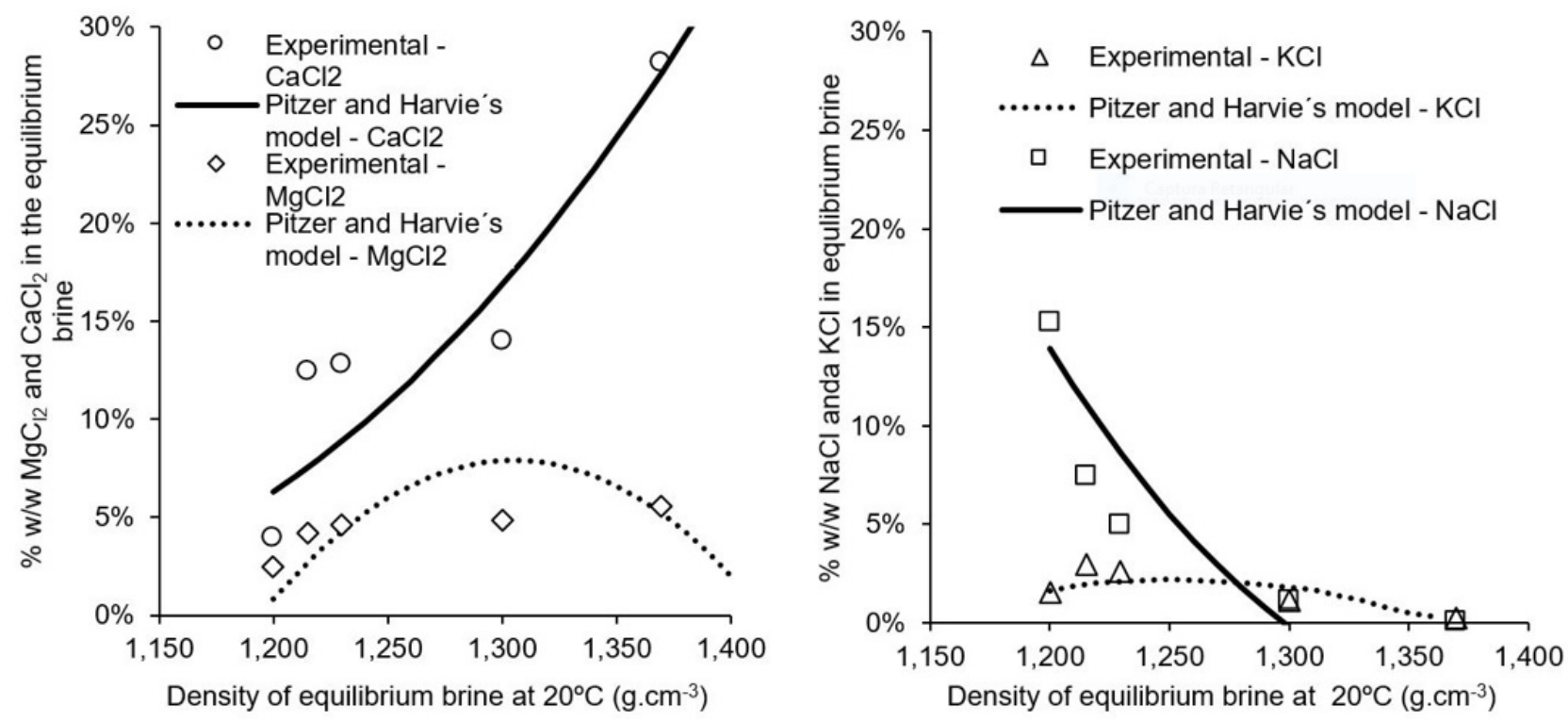

Figure I. Comparison between predicted Pitzer and Harvie's model [7, 9] and experimental data for aqueous system $\mathrm{Na}-\mathrm{K}-\mathrm{Mg}-\mathrm{Ca}-\mathrm{Cl}$ at $20^{\circ} \mathrm{C}$ : (a) $\mathrm{CaCl}_{2}$ and $\mathrm{MgCl}_{2}$ and (b) $\mathrm{KaCl}$ and $\mathrm{NaCl}$.

the other salts found by the Pitzer's and Harvie's models. Figure I $\mathrm{b}$ shows a good agreement between the experimental and calculated results for I-I electrolytes, sodium chloride $(\mathrm{NaCl})$ and potassium chloride $(\mathrm{KCl})$. The systems showed an interesting behavior, always crystallizing sodium chloride and reaching the saturation in $\mathrm{KCl}$, with a density of about $1.230 \mathrm{~g} . \mathrm{cm}^{-3}$ (test 3 ) at $20^{\circ} \mathrm{C}$, where about of $2 \% \mathrm{w} / \mathrm{w}$ of solid phase composition was $\mathrm{KCl}$.

Figure 2 shows that sodium chloride $(\mathrm{NaCl})$ or Halite represented in diffractograms by the letter $\mathrm{H}$ precipitates in all tests, while potassium chloride $(\mathrm{KCl})$ or Sylvite, indicated by the letter $\mathrm{S}$ may started to crystallize in test 3 , but it was only identified in test 4 (Figure 2d). The carnallite $\left(\mathrm{KCl} \cdot \mathrm{MgCl}_{2} \cdot 6 \mathrm{H}_{2} \mathrm{O}\right)$ and bischofite $\left(\mathrm{MgCl}_{2} \cdot 6 \mathrm{H}_{2} \mathrm{O}\right)$ salts may have crystallized in test 4 (Figure 2d), but were not identified by X-ray. Tacahydrate $\left(\mathrm{MgCl}_{2} \cdot \mathrm{CaCl}_{2} \cdot 12 \mathrm{H}_{2} \mathrm{O}\right)$ and anthracite $\left(\mathrm{CaCl}_{2} \cdot 6 \mathrm{H}_{2} \mathrm{O}\right)$ could have precipitated in test 5 (Figure $2 \mathrm{e}$ ), but were not identified by $\mathrm{X}$-ray too.

\subsection{Use of Pitzer and Harvie's Model to Evaluate the Separation of Saleable Salts from Brines Represented by the Na-K-Mg-Ca-Cl System}

The Pitzer's and Harvie's models [7,9] were used to simulate the process to obtain saleable salts from natural brine containing $\mathrm{Na}-\mathrm{K}-\mathrm{Mg}-\mathrm{Ca}-\mathrm{Cl}$. The composition of liquid phase obtained in the Test I was assumed as the same of feed brine due to its saturated condition in $\mathrm{NaCl}$, commonly seen in most brines used to produce $\mathrm{KCl}$.

A solar evaporation process has been designed for the extraction of potassium chloride from brines. The basic streams for the material balance around a single solar pond is shown in Figure 3 where: (i) leakage is the brine lost from the pond through porous dikes and floors. The quantity of leakage is usually described in $\mathrm{kg}$ per day and it is a function of the pond area [13].

According proposed by Butts [14], it was assumed a leakage of $0.01 \mathrm{I} \mathrm{kg} / \mathrm{day} / \mathrm{m}^{2}$; (ii) the water evaporated is usually expressed in $\mathrm{mm} /$ day or $\mathrm{kg} / \mathrm{day} / \mathrm{m}^{2}$. For steps I, 2, 3 and 4 , it was assumed $3.5,2.8,2.0$ and $1.50 \mathrm{~kg}$ of water evaporated per day per $\mathrm{m}^{2}$; (iii) entrainment is related to the brine that is lost attached to the salts deposit. As the salt crystals grow or accumulate on the pond floor, voids are created and some brine is trapped therein. The quantity of entrainment is a function of the quantity and type of salt deposited. The entrainment is generally expressed as a weight percent of the combined salts in the deposit and the entrained brine. It was assumed an entrainment loss of $15 \%$ in all steps. Salts combined to entrainment are here denominated impregnated salts.

Generally, the brine concentrations throughout each solar pond are uniform and equal to the concentration in the brine that leaves each step. This observation is a key assumption for the pond material balance. It was assumed that the leakages and the exit brines have the same concentration, so these streams can be created as a single stream to simplify the material balance.

For fixed concentrations at the entrance and exit points of the pond, the material balance is represented by a system of five variables: flowrate of feeding brine, flowrate of exit brine, evaporation rate, amount and composition of salts formed and pond area. The brines and salts compositions were calculated by the Pitzer and Harvie's model [7,9], and it is described in item 3.I. Of these five variables, only two are independent. By establishing the value of any two of these variables, the system may be solved and the material balance is obtained. 

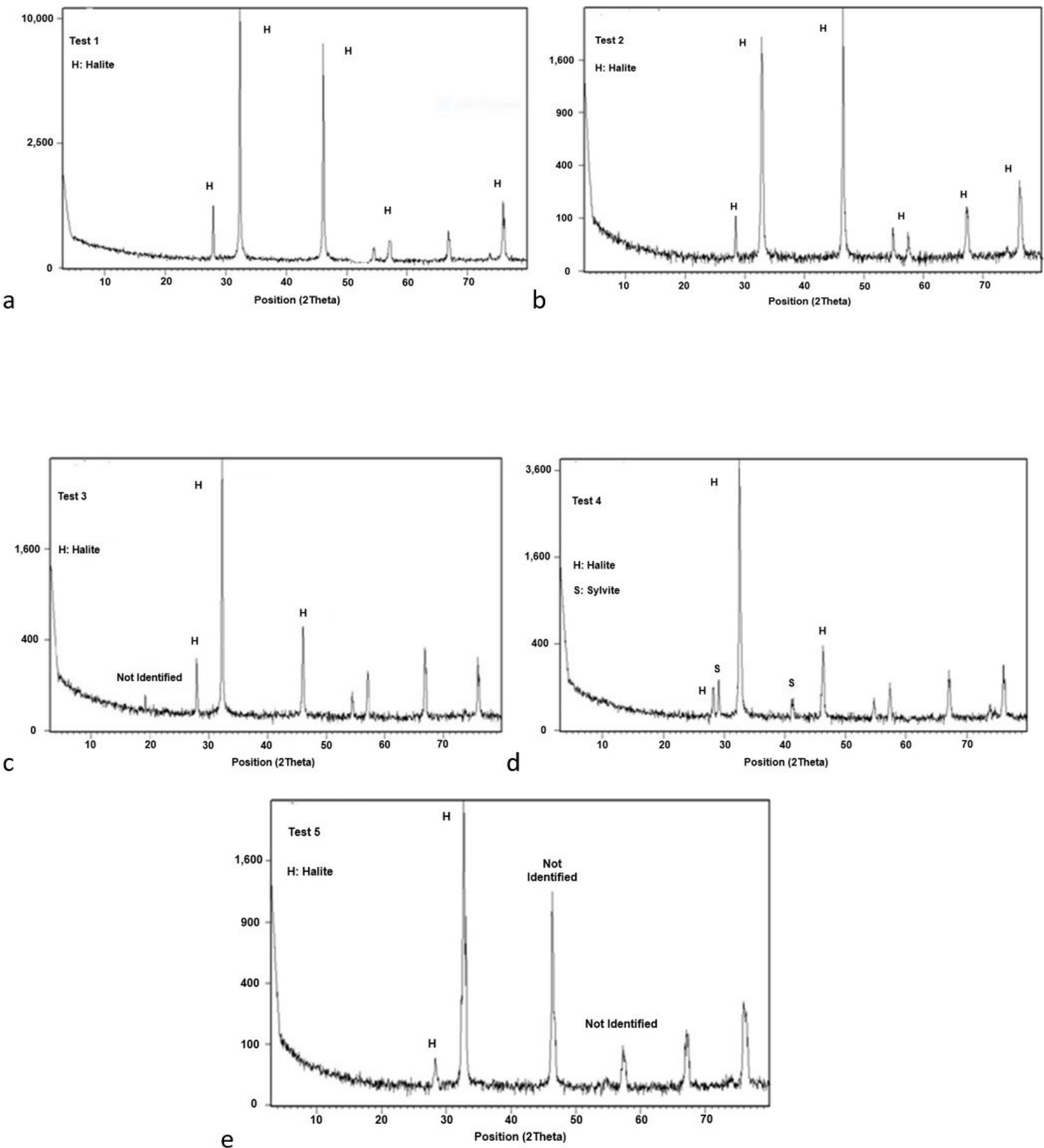

Figure 2. X ray diffractograms for crystallized salts produced in (a) Test I, (b) Test 2, (c) Test 3, (d) Test 4 and (e) Test 5.

The overflow brine from Step I feeds the Step 2, the overflow brine from Step 2 feeds the Step 3 and the overflow brine from Step 3 feeds the Step 4. The overflow brine from Step 4 is called bittern brine, rich in the most soluble salts, like, $\mathrm{MgCl}_{2}$ and $\mathrm{CaCl}_{2}$. Table 5 shows the results of the material balance for Step I, Step 2 and Step 3 using solar evaporation process to crystallize the desired salt. Table 6 shows the composition of feed and overflow brines.
According to the solubility calculated by the Pitzer and Harvie's model $[7,9]$ and the material balance, a sequence of four stages could lead to the crystallization of following salts:

$\checkmark$ Step I: halite $(84 \% \mathrm{w} / \mathrm{w}$ of $\mathrm{NaCl})$;

$\checkmark$ Step 2: sylvinite $(58 \% \mathrm{w} / \mathrm{w}$ of $\mathrm{NaCl}+16 \% \mathrm{w} / \mathrm{w}$ of $\mathrm{KCl}$ ); 


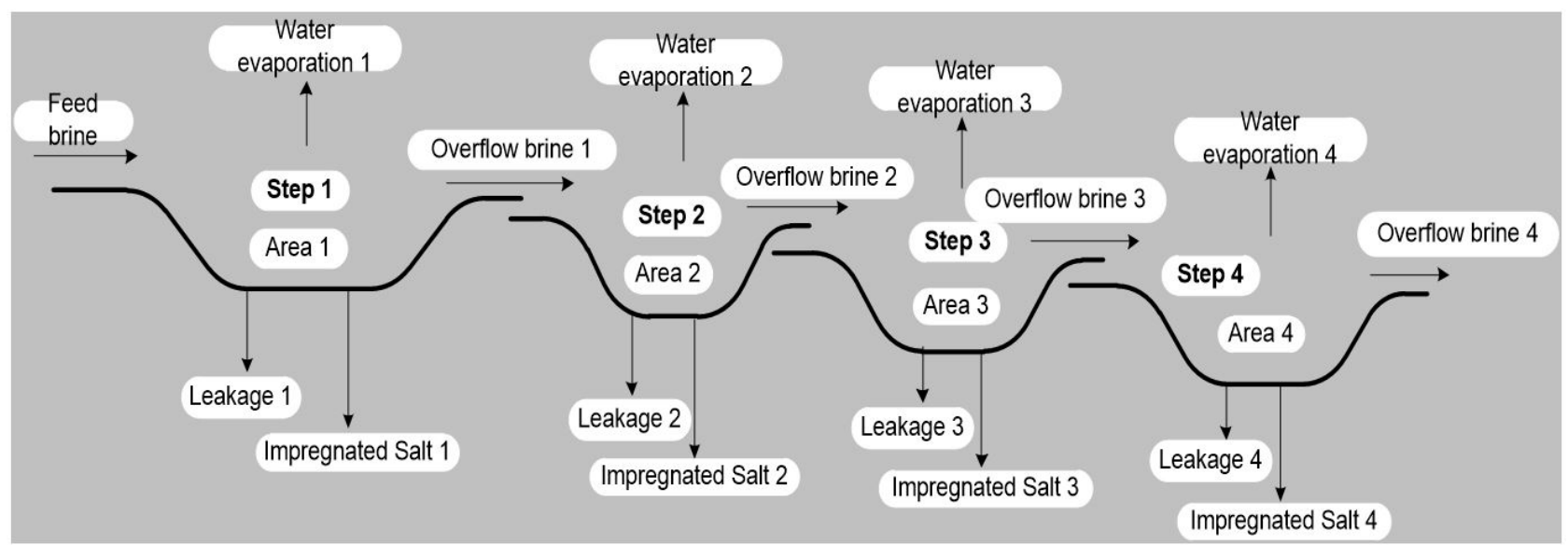

Figure 3. Basic streams of a solar pond for Step I, 2, 3 and 4.

Table 5. Material mass balance results in solar ponds

\begin{tabular}{|c|c|c|c|c|}
\hline & $\begin{array}{c}\text { Step } \\
\text { I }\end{array}$ & $\begin{array}{c}\text { Step } \\
2\end{array}$ & $\begin{array}{c}\text { Step } \\
3\end{array}$ & $\begin{array}{c}\text { Step } \\
4\end{array}$ \\
\hline Pond area $\left(\mathrm{m}^{2}\right)$ & 2,442 & 579 & 693 & 2,157 \\
\hline Feed brine $(\mathrm{kg} / \mathrm{h})$ & 1000 & 482 & 385 & 300 \\
\hline Water evaporation $(\mathrm{kg} / \mathrm{h})$ & 356 & 68 & 58 & 135 \\
\hline Leakage (kg/h) & 1.12 & 0.27 & 0.32 & 0.99 \\
\hline Impregnated salts $(\mathrm{kg} / \mathrm{h})$ & 160.43 & 29.29 & 27.17 & 93.88 \\
\hline Entrainment $(\mathrm{kg} / \mathrm{h})$ & 24.06 & 4.39 & 4.08 & 14.08 \\
\hline Non impregnated salts $(\mathrm{kg} / \mathrm{h})$ & 136.36 & 24.90 & 23.09 & 79.80 \\
\hline Overflow brine $(\mathrm{kg} / \mathrm{h})$ & 482.40 & 385.25 & 300.00 & 71.00 \\
\hline$\%$ accumulated evaporated water & 47 & 56 & 64 & 82 \\
\hline \multicolumn{5}{|c|}{ Composition of impregnated salts (\%w/w) } \\
\hline $\mathrm{NaCl}$ & 72.66 & 56.47 & 6.41 & 3.49 \\
\hline $\mathrm{KCl}$ & 0.45 & 15.46 & 4.11 & 3.29 \\
\hline $\mathrm{MgCl}_{2}$ & 0.74 & 0.92 & 61.01 & 4.90 \\
\hline $\mathrm{CaCl}_{2}$ & 1.56 & 1.82 & 3.66 & 63.41 \\
\hline Total water & 24.59 & 25.33 & 24.81 & 24.91 \\
\hline \multicolumn{5}{|c|}{ Composition of non-impregnated salts (\%w/w) } \\
\hline $\mathrm{NaCl}$ & 84 & 58 & 4 & 3 \\
\hline $\mathrm{KCl}$ & 0 & 16 & 3 & 2 \\
\hline $\mathrm{KCl} \cdot \mathrm{MgCl}_{2} \cdot 6 \mathrm{H}_{2} \mathrm{O}$ & 0 & 0 & 4 & 6 \\
\hline $\mathrm{MgCl}_{2} \cdot 6 \mathrm{H}_{2} \mathrm{O}$ & 0 & 0 & 81 & 0 \\
\hline $\mathrm{CaCl}_{2} \cdot 6 \mathrm{H}_{2} \mathrm{O}$ & 0 & 2 & 0 & 75 \\
\hline Free water $(\% \mathrm{w} / \mathrm{w})$ & 16 & 24 & 9 & 14 \\
\hline $\begin{array}{l}\% \mathrm{w} / \mathrm{w} \text { of feed } \mathrm{KCl} \text { crystallized } \\
\text { (accumulated) }\end{array}$ & 5 & 34 & 42 & 62 \\
\hline $\begin{array}{l}\% \mathrm{w} / \mathrm{w} \text { of feed } \mathrm{KCl} \text { crystallized } \\
\text { (in the respective Step) }\end{array}$ & 5 & 30 & 7 & 20 \\
\hline
\end{tabular}

Step 3: A mixture of sylvinite $(4 \% \mathrm{w} / \mathrm{w}$ of $\mathrm{NaCl}+$ $2 \% \mathrm{w} / \mathrm{w}$ of $\mathrm{KCl})$, carnallite $\left(4 \% \mathrm{w} / \mathrm{w}\right.$ of $\left.\mathrm{KCl} \cdot \mathrm{MgCl}_{2} \cdot 6 \mathrm{H}_{2} \mathrm{O}\right)$ and bischofite $\left(81 \% \mathrm{w} / \mathrm{w}\right.$ of $\left.\mathrm{MgCl}_{2} \cdot 6 \mathrm{H}_{2} \mathrm{O}\right)$;

$\checkmark$ Step 4: A mixture of sylvinite $(3 \% \mathrm{w} / \mathrm{w}$ of $\mathrm{NaCl}+$ $2 \% \mathrm{w} / \mathrm{w}$ of $\mathrm{KCl})$, carnallite $\left(6 \% \mathrm{w} / \mathrm{w}\right.$ of $\left.\mathrm{KCl} \cdot \mathrm{MgCl}_{2} \cdot 6 \mathrm{H}_{2} \mathrm{O}\right)$ and calcium chloride $\left(75 \% \mathrm{w} / \mathrm{w} \mathrm{CaCl} \cdot 6 \mathrm{H}_{2} \mathrm{O}\right)$.
The feed brine in Step I is saturated in $\mathrm{NaCl}$, but it is not saturated in other salts $\left(\mathrm{KCl}, \mathrm{MgCl}_{2}\right.$ and $\left.\mathrm{CaCl}_{2}\right)$, so this is the first salt to be crystallized in Step I. Considering the amount of evaporated water $(356 \mathrm{~kg} / \mathrm{h})$ and an evaporation rate of $3.5 \mathrm{~mm} /$ day, it will be necessary a pond area of about 2,442 $\mathrm{m}^{2}$. Halite crystallized in Step I could be harvested and fed to a $\mathrm{NaCl}$ Industrial Plant. The brine density at $20^{\circ} \mathrm{C}$ changes from 1.200 to $1.215 \mathrm{~g} . \mathrm{cm}^{-3}$, crystallizing approximately $45 \mathrm{I} \mathrm{kg}$ of halite per I,000 kg of evaporated water. Around $5 \%$ of entering potassium chloride is lost by impregnated brine in the salts.

Saturation in $\mathrm{KCl}$ is achieved in the overflow brine from Step I that feeds Step $2(36.60 \mathrm{~g} / \mathrm{L}$ of $\mathrm{KCl})$. In the solar ponds of Step 2, KCl-rich salts (sylvinite) crystallize. The sylvinite crystallized in Step 2 is collected and fed to an industrial $\mathrm{KCl}$ Plant. The brine density at $20^{\circ} \mathrm{C}$ changes from $I .215$ to $1.230 \mathrm{~g} . \mathrm{cm}^{-3}$, resulting in the crystallization of approximately $433 \mathrm{~kg}$ of salts per I,000 kg of evaporated water. About $30 \%$ of entering potassium will crystallize in this Step. Considering the amount of evaporated water in Step $2(68 \mathrm{~kg} / \mathrm{h})$ and an evaporation rate of $2.8 \mathrm{~mm} /$ day, a pond area of about $579 \mathrm{~m}^{2}$ will be necessary.

A mixture of sylvinite, carnallite and bischofite crystallizes in Step 3. This mixture could be harvested and fed to an industrial $\mathrm{MgCl}_{2}$ Plant as well. The brine density at $20^{\circ} \mathrm{C}$ changes from 1.230 to $1.300 \mathrm{~g} \mathrm{~cm}^{-3}$, crystallizing approximately $470 \mathrm{~kg}$ of salts per I,000 kg of evaporated water. About $7 \%$ of entering potassium will crystallize in this Step. Considering the amount of evaporated water in Step $3(58 \mathrm{~kg} / \mathrm{h})$ and an evaporation rate of $2.0 \mathrm{~mm} /$ day, a pond area of about $693 \mathrm{~m}^{2}$ will be necessary.

A mixture of sylvinite, carnallite and calcium chloride crystallizes in Step 4. This mixture could be harvested and fed to an industrial $\mathrm{CaCl}_{2}$ Plant as well. The brine density at $20^{\circ} \mathrm{C}$ changes from 1.300 to $1.370 \mathrm{~g} . \mathrm{cm}^{-3}$, crystallizing approximately $696 \mathrm{~kg}$ of salts per $1,000 \mathrm{~kg}$ of evaporated water. About $20 \%$ of entering potassium will crystallize in this step. Considering the amount of evaporated water in 
Table 6. Composition of initial and overflow brines, densities, $\mathrm{KCl}$ and $\mathrm{MgCl}_{2}$ concentrations and total soluble solids

\begin{tabular}{|c|c|c|c|c|c|}
\hline Component & Feed & Overflow Step I & Overflow Step 2 & Overflow Step 3 & Overflow Step 4 \\
\hline $\mathrm{NaCl}(\% w / w)$ & 15.25 & 7.44 & 5.01 & 1.13 & 0.15 \\
\hline \multicolumn{6}{|c|}{$\% \mathrm{w} / \mathrm{w}$} \\
\hline $\mathrm{KCl}$ & 1.53 & 3.01 & 2.59 & 1.09 & 0.26 \\
\hline $\mathrm{MgCl}_{2}$ & 2.50 & 4.93 & 6.10 & 5.97 & 18.68 \\
\hline $\mathrm{CaCl}_{2}$ & 5.20 & 10.24 & 12.67 & 23.50 & 15.40 \\
\hline Total water & 75.52 & 74.38 & 73.62 & 68.30 & 65.52 \\
\hline Density at $20^{\circ} \mathrm{C}\left(\mathrm{g} \cdot \mathrm{cm}^{-3}\right)$ & 1.200 & 1.215 & 1.230 & 1.300 & 1.370 \\
\hline $\mathrm{KCl}\left(\mathrm{g} \cdot \mathrm{L}^{-1}\right)$ & 18.34 & 36.60 & 31.91 & 14.20 & 3.50 \\
\hline $\mathrm{MgCl}_{2}+\mathrm{CaCl}_{2}\left(\mathrm{~g} \cdot \mathrm{L}^{-1}\right)$ & 92 & 184 & 231 & 383 & 467 \\
\hline $\begin{array}{l}\text { Total soluble solids } \\
\left(\mathrm{g} \cdot \mathrm{L}^{-1}\right)\end{array}$ & 294 & 311 & 324 & 412 & 472 \\
\hline
\end{tabular}

Step 4 (I $35 \mathrm{~kg} / \mathrm{h})$ and an evaporation rate of $1.5 \mathrm{~mm} /$ day, a pond area of about $2,157 \mathrm{~m}^{2}$ will be necessary. The brine leaving Step 4 has small amounts of $\mathrm{NaCl}$ and $\mathrm{KCl}$, therefore upon further processing (above a brine density of $\mathrm{I} .370 \mathrm{~g} . \mathrm{cm}^{-3}$ ) mainly magnesium and calcium salts are expected to crystallize.

Due to the low $\mathrm{KCl}$ and high $\mathrm{MgCl}_{2}$ and $\mathrm{CaCl}_{2}$ contents in the impregnated salts of Step 3 and 4, it is not recommended to feed them to an industrial $\mathrm{KCl}$ Plant, while it is suggested to feed the impregnated salt from Step 2, which contains a high $\mathrm{KCl}$ content $(15.46 \% \mathrm{w} / \mathrm{w})$ and low $\mathrm{MgCl}_{2}$ $(0.92 \% \mathrm{w} / \mathrm{w})$ and $\mathrm{CaCl}_{2}(\mathrm{I} .82 \% \mathrm{w} / \mathrm{w})$ contents. Considering feeding only the salt from Step 2 , a total $\mathrm{KCl}$ recovery from the solar pond of $30 \%$ (only from Step I), a KCl recovery in the industrial Plant of $70 \%$ and an on-stream factor of $90 \%$ (values assumed), the industrial Plant will result in about 48 ton of solid residues, $93 \mathrm{~m}^{3}$ of bittern brine, 127 ton of evaporated water and an area of $103 \mathrm{~m}^{2}$ of solar pond per ton of $\mathrm{KCl}\left(60 \% \mathrm{w} / \mathrm{w}\right.$ of $\left.\mathrm{K}_{2} \mathrm{O}\right)$ produced.

\section{CONCLUSIONS}

The experimental solubility data for $\mathrm{Na}-\mathrm{K}-\mathrm{Mg}-\mathrm{Ca}-\mathrm{Cl}$ aqueous systems compared well with the Pitzer's and Harvie's models. The models predicted the crystallization path found experimentally and was used to design a fractional crystallization process with four evaporation steps. This result will be useful for solubility prediction in more complicated systems and supply a theoretical basis for the extraction of salts from aqueous solution representing the $\mathrm{Na}-\mathrm{K}-\mathrm{Mg}-\mathrm{Ca}-\mathrm{Cl}$ aqueous systems, for instance, $\mathrm{NaCl}, \mathrm{KCl}, \mathrm{KCl} . \mathrm{MgCl}_{2} \cdot 6 \mathrm{H} 2 \mathrm{O}$, $\mathrm{MgCl}_{2} \cdot 6 \mathrm{H} 2 \mathrm{O}, \mathrm{MgCl}_{2} \cdot \mathrm{CaCl}_{2} .12 \mathrm{H}_{2} \mathrm{O}$ and $\mathrm{CaCl}_{2} \cdot 6 \mathrm{H}_{2} \mathrm{O}$.

\section{Acknowledgements}

The authors are thankful to Vale S.A., especially to Patrice Mazzoni and Keila Gonçalves for authorizing the publication of this work, Nancy Parada, consultant of chemicals from brines, and Vale's Mineral Development Centre technicians for participating in the study.

\section{REFERENCES}

I Yang J, Peng J, Duan Y, Tian C, Ping M. The phase diagrams and pitzer model representations for the system $\mathrm{KCl}+\mathrm{MgCl} 2+\mathrm{H} 2 \mathrm{O}$ at 50 and $75^{\circ} \mathrm{C}$. Russian Journal of Physical Chemistry A. 2012;86(I3): 1930-I 935 .

2 Zuvic P, Parada N, Vergana L. Recovery of potassium chloride, potassium sulfate and boric acid from the salar de atacama brine. In: Proceedings of the 66th International Symposium on Salts; May 1983; Toronto, Canada. Naples: Salt Institute; 1983. vol. II.

3 Wang X, Miller JD, Cheng F, Cheng H. Potash flotation practice for carnallite resources in the Qinghai Province, PRC. Minerals Engineering. 2014;66-68:33-39.

4 Silva RG, Secker M, Rocha SDF, Saturnino D, Oliveira EG. Thermodynamic modeling of phases equilibrium in aqueous systems to recover potassium chloride from natural brines. Journal of Materials Research and Technology. 2016;6(1):57-64. http://dx.doi.org//0.1016/j.jmrt.2016.05.006.

5 Song P, Yao Y. Thermodynamics and phase diagram of the salt lake brine system at 298.15 K: V. Model for the system $\mathrm{Li}+, \mathrm{Na}+, \mathrm{K}+, \mathrm{Mg} 2+/ \mathrm{Cl}-, \mathrm{SO} 42--\mathrm{H} 2 \mathrm{O}$ and its applications. Calphad. 2003;27:343-352.

6 Pitzer KS. Thermodynamics of electrolytes. I. Theoretical basis and general equations. Journal of Physical Chemistry. 1973;77(2):268-277. 
7 Harvie C, Eugster $\mathrm{H}$, Weare J. Mineral equilibria in the six-component seawater system, $\mathrm{Na}-\mathrm{K}-\mathrm{Mg}-\mathrm{Ca}-\mathrm{SO}_{4}-\mathrm{Cl}_{-} \mathrm{H}_{2} \mathrm{O}$ at $25^{\circ} \mathrm{C}$ II: Compositions of the saturated solutions. Geochimica et Cosmochimica Acta. 1982;46:1603.

8 Harvie C, Moller N, Weare J. The prediction of mineral solubilities in natural waters: the $\mathrm{Na}-\mathrm{K}-\mathrm{Mg}-\mathrm{Ca}-\mathrm{H}-\mathrm{Cl}-$ $\mathrm{SO}_{4}-\mathrm{OH}-\mathrm{HCO}_{3}-\mathrm{CO}_{3}-\mathrm{CO}_{2}-\mathrm{H}_{2} \mathrm{O}$ system to high ionic strengths at $25^{\circ} \mathrm{C}$. Geochimica et Cosmochimica Acta. |984;48:723-75।.

9 Pabalan RT, Pitzer K. Thermodynamics of concentrated electrolyte mixtures and the prediction of mineral solubilities to high temperatures for mixtures in the system Na-K-Mg-Cl-SO ${ }_{4}-\mathrm{OH}-\mathrm{H}_{2} \mathrm{O}$. Geochimica et Cosmochimica Acta. 1987;51:2429-2443.

10 Spencer R, Moller N, Weare J. The prediction of mineral solubilities in natural waters: A chemical equilibrium model for the Na-K-Ca-Mg-Cl-SO $-\mathrm{H}_{2} \mathrm{O}$ system at temperatures below $25^{\circ} \mathrm{C}$. Geochimica et Cosmochimica Acta. 1990;54:575-590.

I I Marcus Y, Soffer N. Solubilities and vapour pressure in the quinary system. Journal of the Chemical Society, Faraday Transactions I. 1988;84(I0):3575-3585.

12 Zeng DW, Xu WF, Voigt W, Yin X. Thermodynamic study of the system ( $\mathrm{LiCl}+\mathrm{CaCl} 2+\mathrm{H} 2 \mathrm{O})$. The Journal of Chemical Thermodynamics. 2008;40(7): II57-1 165.

13 Harvie $\mathrm{C}$, Weare $\mathrm{JH}$. The prediction of mineral solubilities in natural waters: the $\mathrm{Na}-\mathrm{K}-\mathrm{Mg}-\mathrm{Ca}-\mathrm{Cl}-\mathrm{SO}_{4}-\mathrm{H}_{2} \mathrm{O}$ system from zero to high concentration at $25^{\circ} \mathrm{C}$. Geochimica et Cosmochimica Acta. 1980;44:98I-997.

I4 Butts D. Theory and practice of extracting minerals from brine. Ogden: Great Salt Lake Minerals \& Chemicals Corporation; 1984. (Solar Ponds; vol. I).

Received: 5 Jun. 2017

Accepted: 16 Oct. 2017 